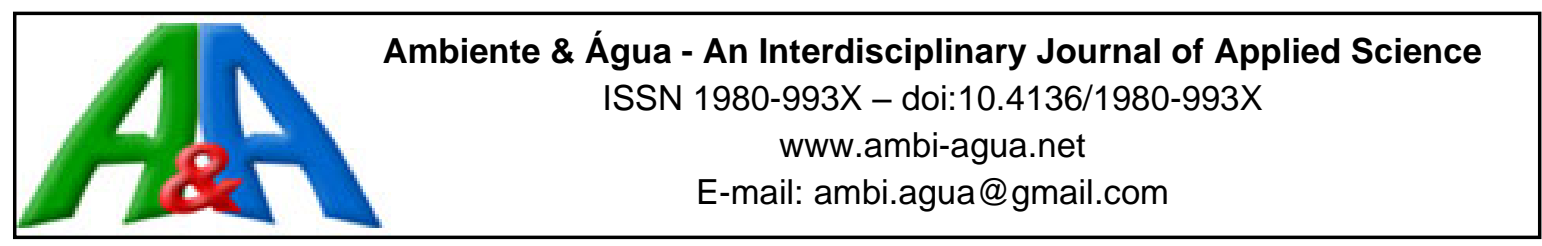

\title{
Quality of drained waters of the irrigated rice frames during the establishment of pre-germinated cultivation system
}

\author{
ARTICLES doi:10.4136/ambi-agua.2642
}

Received: 05 Sep. 2020; Accepted: 17 Mar. 2021

\section{Marthin Zang1(i); Cezar Augusto Gama de Toni1 ${ }^{1}$; Paulo César do Nascimento $^{2 *}$; Cláudio Fioreze $^{3}$; Cássio Martinez Machado1 ${ }^{1}$; Gustavo Ristow Vodzik ${ }^{1}$; Edsleine Ribeiro da Silva ${ }^{2}$; Caio de Melo Mocelin ${ }^{3}$ [D}

\footnotetext{
${ }^{1}$ Faculdade de Agronomia. Universidade Federal do Rio Grande do Sul (UFRGS), Avenida Bento Gonçalves, n 7712, CEP: 91540-000, Porto Alegre, RS, Brazil. E-mail: marthin.zang @ gmail.com, cezardetoni@gmail.com, cassiomartinez@gmail.com,gustavovodzik@gmail.com

${ }^{2}$ Faculdade de Agronomia. Departamento de Solos. Universidade Federal do Rio Grande do Sul (UFRGS), Avenida Bento Gonçalves, n 7712, CEP: 91540-000, Porto Alegre, RS, Brazil. E-mail: edsleine@ hotmail.com ${ }^{3}$ Instituto Federal de Educação, Ciência e Tecnologia do Rio Grande do Sul (IFRS), Avenida Senador Salgado Filho, s/n, CEP: 94410-970, Viamão, RS, Brazil. E-mail: claudio.fioreze@ viamao.ifrs.edu.br, caiomocelin98@gmail.com

*Corresponding author. E-mail: pcnasc@ufrgs.br
}

\begin{abstract}
Irrigated rice (Oriza sativa L.) pre-germinated production systems occupy approximately 100 thousand ha, annually cultivated in Rio Grande do Sul State, mainly in poorly drained areas, and with infestation of competing plants, especially red rice (Oriza sativa L.). This system constitutes the main technologic resource for rice crops produced on an ecological basis, by means of soil tillage and water management. Despite this, water outlets, specifically after seeding, have outstanding agronomic and environmental implications. Loss of nutrients and the physical and chemical quality of drained water have been questioned by public research and environmental institutions. This work evaluated the effects of different soil tillage systems and retention time of water in irrigated rice frames. The experiment was conducted in Viamão town, Rio Grande do Sul State. Two different soil tillage systems and four different times of frame drainage after seeding were investigated. Results showed that the main limiting attributes of water quality were turbidity, biochemical oxygen demand (BOD) and phosphorus (P) content, reaching $1800 \mathrm{TNU}, 115 \mathrm{mg} \mathrm{L}^{-1}$, and $1.6 \mathrm{mg} \mathrm{L}^{-1}$, respectively. These attributes showed values higher than established environmental thresholds. Water quality was inappropriate to discharge directly into water courses, regardless of treatments.An alternative is the immediate placement in rice production areas, in more advanced development stages of plants. Pre-germinated rice crops require a system framework to avoid nutrient loss and consequent reduction of soil fertility.
\end{abstract}

Keywords: irrigated rice, soil tillage, water quality.

\section{Qualidade das águas drenadas dos quadros de arroz irrigado durante o estabelecimento do cultivo no sistema pré-germinado}

\section{RESUMO}

Os sistemas de produções de arroz (Oryza sativa L.) irrigado, pré-germinado ocupam uma

This is an Open Access article distributed under the terms of the Creative Commons Attribution License, which permits unrestricted use, distribution, and reproduction in any medium, provided the original work is properly cited. 
superfície de aproximadamente 100 mil hectares, cultivados anualmente no Estado do Rio Grande do Sul, principalmente em áreas com deficiência de drenagem e com infestação de plantas competidoras, fundamentalmente o arroz vermelho (Oryza sativa L.). Esse sistema constitui a principal tecnologia para o cultivo de arroz de base ecológica, através do preparo do solo e do manejo da água nos quadros cultivados. Não obstante, a retirada da água dos quadros, especificamente após semeadura, tem implicações agronômicas e ambientais de destaque. A perda de nutrientes e a qualidade física e química da água drenada têm sido questionadas por instituições públicas, ambientais e de pesquisa. O objetivo desse trabalho foi avaliar os efeitos de diferentes formas de preparo do solo, assim como o tempo de permanência da água nos quadros de arroz irrigado pré-germinado. O experimento foi conduzido no município de Viamão - RS. Foram utilizados dois tipos de implementos para preparo do solo, associados a quatro tempos de drenagem dos quadros após a semeadura. Os resultados indicaram que os atributos mais limitantes em relação à qualidade da água, foram a turbidez, a demanda bioquímica de oxigênio (DBO) e os teores de fósforo, que chegaram a $1800 \mathrm{UNT}, 115 \mathrm{mg} \mathrm{L}^{-1}$ e 1,6 $\mathrm{mg} \mathrm{L}^{-1}$, respectivamente. A turbidez, assim como as concentrações de $\mathrm{P}$ e DBO, apresentaram-se superiores ao limite legal em todos os tratamentos avaliados. Devido o envolvimento da água no preparo do solo, sua qualidade foi imprópria para o descarte diretamente nos cursos hídricos, independentemente do implemento utilizado e dos diferentes períodos de decantação avaliados. Dessa forma, uma alternativa é a utilização dessas águas imediatamente em áreas de produção com arroz em estágios mais avançados de desenvolvimento. As lavouras de arroz pré-germinado, sobretudo nas produções de base ecológica, demandam uma adequação do sistema ao estabelecido pela legislação, contribuindo também para evitar perdas de nutrientes e a consequente redução da fertilidade dos solos.

Palavras-chave: arroz irrigado, preparo do solo, qualidade da água.

\section{INTRODUCTION}

Rio Grande do Sul State is responsible for $70 \%$ of rice production in Brazil, with predominance of the long-thin class (SOSBAI, 2018). The pre-germinated rice production system occupies a significant area of 115.7 thousand ha in the State (IRGA, 2019). This system comprises a set of operations and techniques for soil tillage, water management, sowing and establishment of rice plants under irrigated cultivation, using pre-germinated seeds, broadcast in level plots, usually separated by fixed and completely flooded partitions. The system originated in Santa Catarina State, introduced by immigrants during the XX century, and today occupies $98 \%$ of irrigated rice areas. In Rio Grande do Sul State, it occupies $11 \%$ of cultivated area. The adoption and expansion of this system is fundamentally limited by costs of trained labor and planting.

In a long-term experiment, Carlos et al. (2015) verified that pre-germinated systems showed higher productivity in comparison with conventional and no-till systems, probably due to better competing plant control as a consequence of seeding in previously waterlogged soil. This method can be performed with lower costs and higher efficiency in comparison with controls based on chemical principles (Avila et al., 1997). Besides this, soil tillage and levelling quality, associated with adequate soil fertility management, irrigation and drainage, are fundamental to obtain optimum yields (Anghinoni et al., 2020). On the other hand, it may cause some problems, like the occurrence of birds and mollusks (Pomacea 2ulphur2rize L.) during the emergence period, and lack of cultivars adapted to this system (Petrini et al., 2004). Pregerminated rice production is used in several countries in the world with good results with respect to quality and resistance against problems like climate stress. Besides Brazil, with 20\% of cultivated area, other countries adopted the system, using it in $90 \%$ and $30 \%$ of cultivated areas in Europe and USA, respectively, and other countries in Latin America, Asia and Africa. 
Guerra et al. (1998), focusing on rice cultivation in Asia, detected pre-germinated production systems as an option to save water, due to thinner surface water layer and less water percolation compared to transplantation systems. Tadesse et al. (2013) found higher and faster plant development, avoiding droughts in terminal periods of the cycle, beyond other environmental stresses. Tonthong et al. (2018), working in Ethiopia, showed greater germinability of pregerminated seeds, even when they are stored for periods of eight weeks, compared with dry seeds. These authors emphasized the increase of the pre-germinated practice in Southeast Asia.

Some changes may also be noted in the chemical composition of seeds and plant growth in pre-germinated system, like more availability of some elements (calcium, iron, manganese) induced by metabolic processes, as well as quantitative and qualitative alterations in protein content (Shallan et al, 2010; Kupkanchanakul et al., 2018). Rio Grande do Sul State is a pioneer in ecological rice production, always associated with pre-germinated systems (Zang, 2020). This type of production, free of pesticides, began in an agrarian reform settlement in 1999, in small areas between 3 and 4 ha in the Porto Alegre Metropolitan Region (Vignolo, 2010). In the "Filhos de Sepé" settlement (FSS), located in Viamão district, in the Gravataí River Watershed, organic production began in 2001, in an area of 1.7 ha (Zang, 2020). FSS is responsible for $30 \%$ of ecological basis rice produced in the agrarian reform settlements of Rio Grande do Sul State, whose total extension, in 2020, was 3,470 ha (Anghinoni et al., 2020; Miranda et al., 2016).

Despite the importance of this production system, there are still some technical and environmental problems, like the quality of the water released from these areas, especially after sowing. Significant solid particles and nutrients derived from fertilisers are released after first drainage (Garcia et al., 2005; Marchezan et al., 2007a). Consequently, studies have shown that some attributes, such as turbidity, greatly exceed the limits established by CONAMA (2005) for wastewater (Resolution no. 357/05) (Table 1) (Marchezan et al., 2007b; Mattos et al., 2012; Scivittaro et al., 2010). This resolution states that water from rice frames, if returned to the main rivers in the watershed, needs to have quality compatible with uses like fishing, and irrigation for fruits and vegetables.

In this study we hypothesized that some variables of the production system, such as the method of soil tillage and the time the water remains in the plots after the sowing of rice, influence the physical and chemical quality of the wastewater and the loss of soil and nutrients. The aims of this study therefore were: a) to evaluate the physical and chemical characteristics of drainage water from the cultivation of pre-germinated rice under different types of soil preparation and the amount of time the water remains in the plots after sowing; and, b) to compare the quality of this water with the standards established and defined by environmental resolutions.

\section{MATERIAL AND METHODS}

The work was carried out in the district of Viamão, RS, in an area of the FSS located 35 $\mathrm{km}$ from Porto Alegre, in the Pampa biome, between the Coastal Plain and the Central Depression of the state (Figure 1).

The geology of the area is composed of little-consolidated sedimentary material of wind and colluvium-lagoon origin, with variable selection and stratifications of silty-clay material (CPRM, 2008). According to the Köppen system, the climate in the study region is classified as type Cfa, subtropical, 3ulphur3rized by rainfall every month (CGHG, 2012). The mean total annual rainfall is $1,309 \mathrm{~mm}$, with no major difference in distribution between seasons.

The FSS is located in the Environmental Protection Area of "Banhado Grande", the largest sustainable environmental conservation unit in the state.

FSS is also located in Gravatai River Basin, considered to be the most sensitive in the region, and one of the most degraded in the state. According to FEPAM (2020), and mainly 
based on the indicators of total phosphorus, E. coli and dissolved oxygen, Gravataí River has extremely poor water quality.

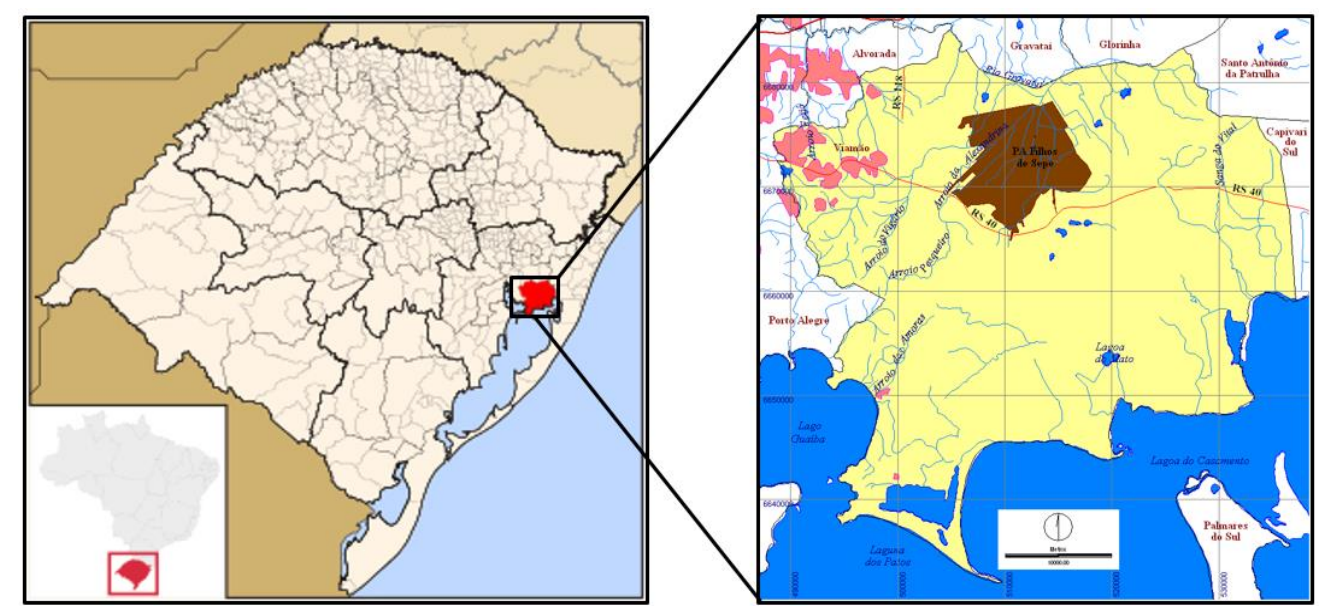

Figure 1. Location of the district of Viamão in Rio Grande do Sul, showing the Filhos de Sepé settlement.

Ecologically based rice in the FSS is produced in an area varying from 1200 to 1600 ha over the last six agricultural years (Zang, 2020). The experimental area comprises approximately 6 ha of flat relief ( 0 to $2 \%$ slope). The land has imperfect drainage, with the soil classified as a Haplic Planosol according to EMBRAPA classification (2018), and Gleyic Eutric Planosol according to FAO-WRB classification (IUSS, 2015). The experiment was conducted in October 2018.

The main characteristics of the soil are: $225 \mathrm{~g} \mathrm{~kg}^{-1}$ clay; $120 \mathrm{~g} \mathrm{~kg}^{-1}$ silt; $655 \mathrm{~g} \mathrm{~kg}^{-1}$ sand; pH 5.3; $3.0 \mathrm{mg} \mathrm{kg}^{-1} \mathrm{P} ; 12.0 \mathrm{mg} \mathrm{kg}^{-1} \mathrm{~S} ; 15.8 \mathrm{mg} \mathrm{kg}^{-1} \mathrm{~K} ; 20.4 \mathrm{mg} \mathrm{kg}^{-1} \mathrm{Na} ; 8.5 \mathrm{~g} \mathrm{~kg}^{-1}$ total organic carbon (TOC); $3.3 \mathrm{cmol}_{\mathrm{c}} \mathrm{kg}^{-1} \mathrm{Ca} ; 1.4 \mathrm{cmol}_{\mathrm{c}} \mathrm{kg}^{-1}$ of $\mathrm{Mg} ; 0.18 \mathrm{cmol}_{\mathrm{c}} \mathrm{kg}^{-1} \mathrm{of} \mathrm{Al}^{3+}$ and $4.6 \mathrm{cmol}_{\mathrm{c}}$ $\mathrm{dm}^{-3}$ of $\mathrm{Al}^{3+}+\mathrm{H}^{+}$. The experimental area has been cultivated with ecological-based rice, certified as organic, for around ten years, with one or two years of fallow. Sowing density was $150 \mathrm{~kg} \mathrm{ha}^{-1}$. Liming at a dose of $600 \mathrm{~kg} \mathrm{ha}^{-1}$ was carried out in the area. Basic fertilizer was applied in late September, consisting of $1500 \mathrm{~kg} \mathrm{ha}^{-1}$ poultry litter with a dry basis composition $\left(65^{\circ} \mathrm{C}\right)$ of $660 \mathrm{~g} \mathrm{~kg}^{-1}$ dry matter, $320 \mathrm{~g} \mathrm{~kg}^{-1} \mathrm{C} ; 20 \mathrm{~g} \mathrm{~kg}^{-1} \mathrm{~N} ; 31.5 \mathrm{~g} \mathrm{~kg}^{-1} \mathrm{P}_{2} \mathrm{O}_{5} ; 29.0 \mathrm{~g} \mathrm{~kg}^{-1} \mathrm{~K}_{2} \mathrm{O}$; $82.0 \mathrm{~g} \mathrm{~kg}^{-1} \mathrm{Ca}^{2+} ; 10.0 \mathrm{~g} \mathrm{~kg}^{-1} \mathrm{Mg}^{2+} ; 5.9 \mathrm{~g} \mathrm{~kg}^{-1} \mathrm{~S} ; 7.2 \mathrm{~g} \mathrm{~kg}^{-1} \mathrm{Na}^{+} ; 44 \mathrm{mg} \mathrm{kg}{ }^{-1} \mathrm{~B} ; 41 \mathrm{mg} \mathrm{kg}^{-1} \mathrm{Cu}$; $480 \mathrm{mg} \mathrm{kg}^{-1} \mathrm{Zn} ; 1314 \mathrm{mg} \mathrm{kg}^{-1} \mathrm{Mn}$ and $4384 \mathrm{mg} \mathrm{kg}^{-1}$ total Fe.

Immediately after fertilizer application, the area was flooded with a water depth of around $0.10 \mathrm{~m}$. Two soil tillage systems practiced, a) hydraulic levelling harrow (LH) and b) rotary hoe (RH) as specified by Anghinoni et al. (2020). Final tillage and levelling of the soil were carried out about 20 days before sowing. Inundation was topped up after tillage, maintaining soil submerged in a water layer of $0.15 \mathrm{~m}$ depth.

The second factor (variable) was the time the plots were drained following sowing. Drainage was carried out at 0,2, 3 and 5 days after sowing (DAS). Using this combination, eight treatments were employed with three replications, giving a total of 24 experimental units. The delineation model was completely randomized; however, the drainage time after sowing was controlled. In this way, the plots where the water was drained sooner after sowing (in the order of $0,2,3$ and 5 DAS) were located from the closest to the farthest position in relation to the main drain. We applied this method since the water from one plot could have entered to others during the flow until the main drain channel. Consequently, this control avoided any influence of their flow on the characteristics of the other plots, drained later.

Samples were collected close to the water outlet of the plots, at opening of the drains and 6 hours after opening. To know previously some issues related to quality of water used in the experiment, two water samples were collected at the entry of the channel to the experimental

Rev. Ambient. Água vol. 16 n. 2, e2642 - Taubaté 2021 
area, called the 'irrigation channel', and also from randomly chosen plots one day before planting. These data were not statistically analyzed and were only used as a reference.

No rainfall was recorded during the collection period. Winds with average gusts $\left(\mathrm{m} \mathrm{s}^{-1}\right)$ of 3.14 were recorded on the day of sowing, 6.39 one day later, 5.95 at 2 DAS, 6.33 at 3 DAS, 4.34 at 4 DAS and 7.11 at 5 DAS, according to data from the Porto Alegre automatic weather station of Inmet. The wind gusts, particularly those concentrated between 06:00 and 17:00 each day, were also greater at $5 \mathrm{DAS}$, with an average of $6.70 \mathrm{~m} \mathrm{~s}^{-1}$, followed by $1 \mathrm{DAS}$, with gusts of $6.30 \mathrm{~m} \mathrm{~s}^{-1}$.

In the field, $\mathrm{pH}$ was determined using a Digimed ${ }^{\circledR}$ portable $\mathrm{pH}$ meter. Aliquots were placed in plastic bottles and stored in refrigerated compartments. The following analyses were carried out in the laboratory: total organic carbon, by ignition after drying; biochemical oxygen demand by $\mathrm{O}_{2}$ consumption in incubated samples; nitric nitrogen by the chromotropic method; ammonia nitrogen by the Kjeldahl method; and suspended and total solids by weighing after drying at 103 to $105^{\circ} \mathrm{C}$, with prior filtration through $0.45 \mu \mathrm{m}$ filters to obtain the former. Turbidity was determined using the nephelometric method. The element contents (aluminium, boron, calcium, copper, 5ulphur, iron, phosphorus, manganese, magnesium, molybdenum, potassium, silicon and zinc) were obtained via triacid digestion, and determined in the extracts using induced plasma atomic absorption spectrophotometry. All determinations were made following APHA et al. (2017) except for nitrogen which ABNT (1992) was used.

The results were analyzed statistically via analysis of variance - ANOVA and Tukey's test at 5\%; in cases of non-parametric data, the Kruskal Wallis test and the post-hoc Dunn test were used. Principal component analysis (multivariate) was also carried out, with the aim of verifying the greatest proximity between treatments (Ferreira, 2008). To do this, the mean data for the attributes under evaluation in each treatment were converted to standard scores.

\section{RESULTS AND DISCUSSION}

The $\mathrm{pH}$ values remained in the range of 7.5 to 8.0 (not shown). The variation between treatments was small ( $p>0.05$ ) and, moreover, fell within the values stipulated for Class II by CONAMA 357/05 (between 6 and 9), and were therefore not considered a restrictive factor.

The water in the irrigation channel showed values for turbidity of 55 NTU. After preparing the soil, these values reached levels higher than the limits established in CONAMA 357/05 (100 NTU) in all treatments (Figure 2).

In experiments conducted in areas of pre-germinated cultivation in Rio Grande do Sul and Santa Catarina, the results of the water analysis from the first drainage showed values for turbidity greater than 100 NTU, regardless of the time of collection (Machado et al., 2006; Molozzi et al., 2006; Mattos et al., 2012).

The water collected before sowing showed better quality than most treatments, indicating that the sowing operation remobilizes some of the particles precipitated during the previous period. This trend is reinforced by the similar behavior found for total solids (Table 1). The RH-0DAS and RH-5DAS treatments showed the highest levels of total solids, at both 0 and 6 hours after opening the drains, albeit with no significant differences for RH-2DAS, LH-0DAS, LH-2DAS or LH-5DAS (the last two only in the ' 6 Hour' collection). Treatments where the water remained for three days after sowing (RH-3DAS and LH-3DAS) showed the best results, regardless of the type of equipment used for soil tillage. On the other hand, the levels of total solids in the water collected from the irrigation channel $\left(240 \mathrm{mg} \mathrm{L}^{-1}\right)$ were much lower than most of the treatments, indicating a lot of turbulence and sediment suspension caused by soil tillage and the remobilisation caused by sowing afterwards.

As an example, the total volume of solids can be calculated using a reference depth of 0.10 $\mathrm{m}$ of water. In this case, for an area of one hectare, a loss of $1 \mathrm{mg} \mathrm{L}^{-1}$ is equivalent to $1 \mathrm{~kg} \mathrm{ha}^{-1}$. Then the lowest and the highest rates of soil loss were 410 and $2300 \mathrm{~kg} \mathrm{ha}^{-1}$, respectively. 


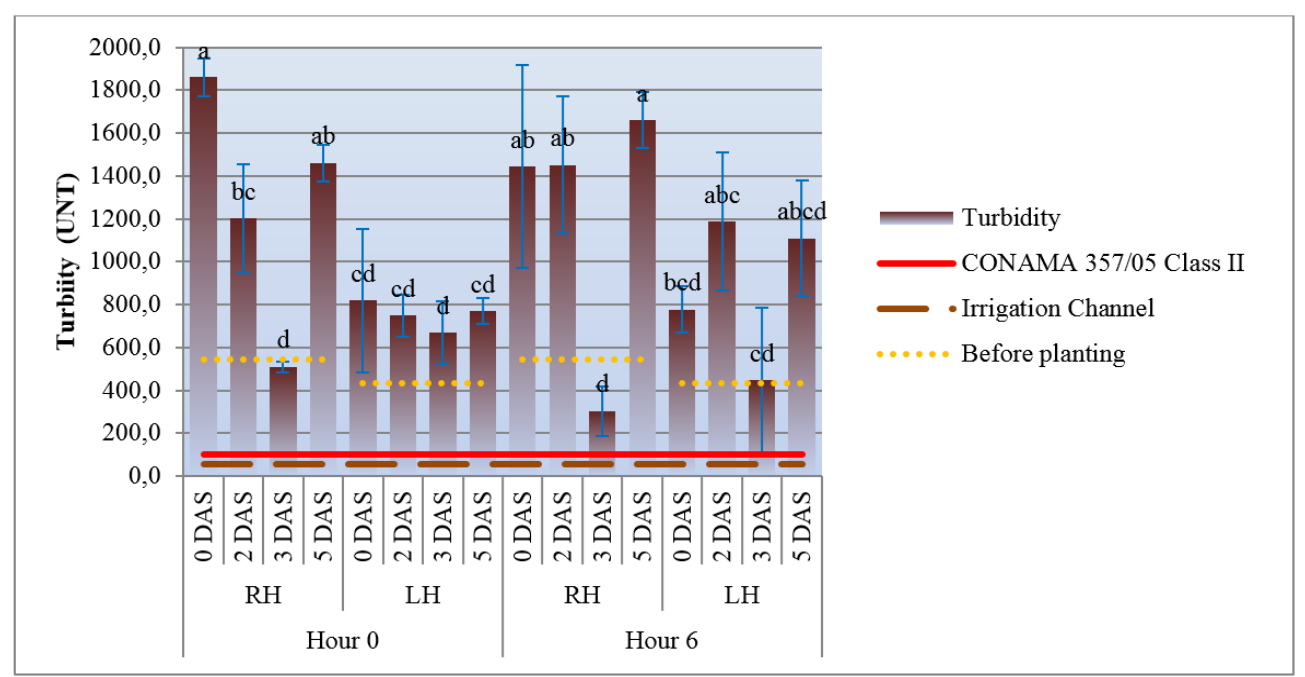

Figure 2. Turbidity values in water drained from crops of pre-germinated irrigated rice under different methods of soil preparation and periods for the water remaining in the plots after sowing, for two collection times.

DAS = Days after sowing (period for the water remaining in the plots after sowing, in days); $\mathrm{LH}=$ hydraulic levelling harrow; $\mathrm{RH}=$ rotary hoe. Hour 0 and 6 refer to the collections made when opening the partitions and 6 hours later. The blue bars represent the standard deviation. Different letters indicate significant differences between treatments at $\mathrm{p}<0.05$ by post-hoc Tukey test.

The biochemical oxygen demand (BOD) indicates the amount of oxygen needed to oxidize the organic matter in the water (Telles and Góis, 2013), and it is related to the release of organic loads in water bodies, mainly from domestic sewage.

This attribute showed a similar behavior to that of turbidity, but with values in the irrigation channel above the limits established by CONAMA 357/05, maintaining this level regardless of the management system (Table 1). BOD and solids, especially in suspended form, are among the main factors to influence turbidity (Miljojkovic et al., 2019). The highest values were seen in RH-ODAS for both collection times after opening the drains. However, comparing the two drain opening times, there was a difference between RH-ODAS and LH-3DAS. The greatest values exceeded $80 \mathrm{mg} \mathrm{L}^{-1}$, far higher than the limit of $5 \mathrm{mg} \mathrm{L}^{-1}$ for Class II of water quality classification. Based on the observed BOD values of irrigation channel, it seems that despite the abrupt increase in wastewater from the plots, this characteristic is intrinsic to the soils and drainage waters of this lowland area, with a tendency for organic matter accumulation, including the formation of more-mobile organic compounds (Felisolla et al., 2019; Nascimento et al., 2010). We state that differences in environment should be considered by government agencies when they are establishing threshold values for attributes. Among the attributes under evaluation, turbidity presented a correlation coefficient $\left(r_{s}\right)$ of 0.78 and 0.72 with total solids and BOD, respectively. As such, turbidity is an indicator of physical and biochemical condition of the water, as well as soil loss.

The ammonia $\mathrm{N}$ content was reduced due to some of the applied treatments, reaching levels below the limits established by CONAMA 357/05, and close to those found in the irrigation channel. Treatments in which water remained in the plots for three days after sowing showed the lowest ammonia $\mathrm{N}$ content. Under tillage with the rotary hoe treatments, the greatest values were detected with 0 and 5 DAS, the latter may be related to the climate conditions, especially the effect of the wind that, when moving the water, caused remobilization and dilution of clayminerals and organic particles.

Considering the values established for intermediate environments (Figure 3), the levels of 
phosphorus found in the irrigation channel are 12 times higher than the limit established by CONAMA 357/05.

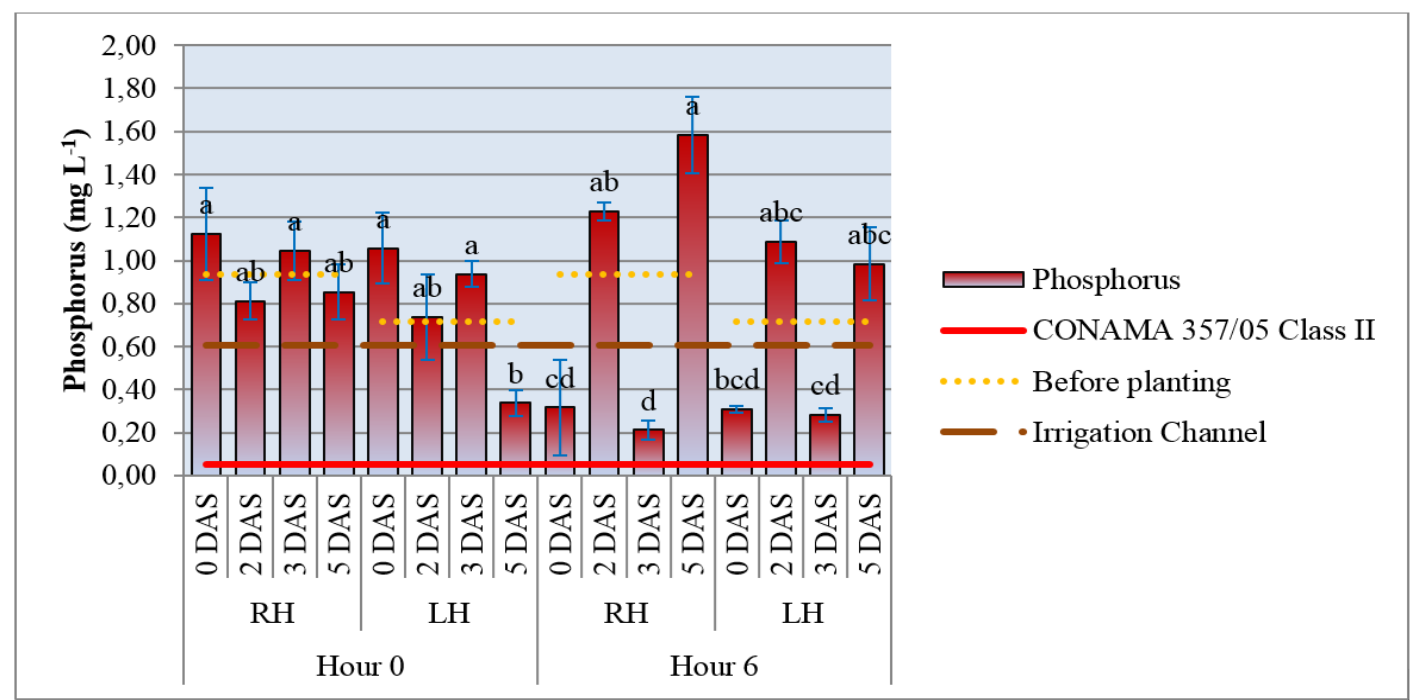

Figure 3. Phosphorus levels in water drained from crops of pre-germinated irrigated rice under different methods of soil preparation and periods for the water remaining in the plots after sowing, for two collection times.

DAS = Days after sowing (period for the water remaining in the plots after sowing, in days); $\mathrm{LH}=$ hydraulic levelling harrow; $\mathrm{RH}=$ rotary hoe Hour 0 and 6 refer to the collections made when opening the partitions and 6 hours later, respectively. The blue bars represent the standard deviation. Values submitted to the Kruskal Wallis test. Different letters indicate significant differences between treatments at $p<0.05$ by post-hoc Tukey test.

This attribute was influenced by the type of management, and some of treatments decreased to below the values found in the channel; however, all of the values were greater than the limit established for Class II framing.

The treatments with higher levels of phosphorus did not show significant difference for the collections at Hour 0, except for LH-5DAS. At Hour 6, the greater values for 2 and 5 DAS are noteworthy, despite only RH-5 DAS showing significant differences at 0 and 3 DAS. The levels were between 0.23 and $1.58 \mathrm{mg} \mathrm{L}^{-1}$, with a relatively high range between treatments. These values correspond approximately to those obtained by Marchezan et al. (2007b), indicating probable influence of fertilizer prior to sowing.

The poor quality of the waters of the Gravataí Basin is mainly due to the levels of phosphorus and the BOD. This finding is corroborated by FEPAM (2020), where in approximately $60 \%$ of the samples, values for total phosphorus exceeded the limit of Class III. Again, we consider this point is an aspect to be considered in legislation, to evaluate the possibility of establishing different threshold values according to environment characteristics. On the other hand, it may be noted that the use of water in these rice irrigated frames increased the phosphorus levels in at least one of the collection times for all the treatments, showing the influences of this use.

There is no normative value for potassium in wastewater (Table 1). However, the data show significant values for the losses of this nutrient. The post-seeding drainage of the water used/involved in soil preparation showed loss of $\mathrm{K}$ ranging from 0.7 to $5.2 \mathrm{mg} \mathrm{L}^{-1}$. Again, water management (drainage time) had an influence, with smaller losses where the water remained for three days in the plot. Other evaluations made in areas of pre-germinated irrigated rice in RS (Marchezan et al., 2001; 2007a; 2007b; Weber et al., 2003; Machado et al., 2006) found a loss of $\mathrm{K}$ from 2.46 to $5.24 \mathrm{~kg} \mathrm{ha}^{-1}$. The loss of nutrients is more significant when drainage is carried out less than two days after preparing the soil. According to Macedo et al. (2001), under 
such conditions, losses of up to $48 \mathrm{~kg} \mathrm{ha}^{-1}$ potassium can occur.

Ammonium - N, Ca, Mg, K, S and P showed lower contents with the use of $\mathrm{LH}$, although they had significant differences with RH mainly in 0 and 2DAS. Major effects of soil disaggregation and nutrients mobilization may be observed when RH is used. Upadhyay and Raheman (2019) showed less soil compaction with the use of levelling harrow compared to rotavator implements. This may increase water percolation, diminishing water, soil and nutrients losses. Besides this, LH may be considered less intensive due to the absence of soil turnover, resulting in less soil pulverization. This lower intensity may promote major aggregate stability, decreasing losses with water flow (Weidhuner et al., 2021). In our study, it seems that RH promoted this pulverization with aggregate disruption, increasing particles suspended in the water. Consequently, this effect neutralized, and even reverted, the possible positive effect of basic fertilizer incorporation in relation to LH. This also increases losses of nutrients.

Comparing collection times, iron ( $\mathrm{Fe})$, aluminium $(\mathrm{Al})$ and silicon $(\mathrm{Si})$ also showed the highest levels in the RH-5DAS, RH-0DAS, RH-2DAS and LH-0DAS treatments, albeit with some difference in order. The greater presence of suspended particles on the day of sowing $(0$ DAS) should be noted, with a tendency for particle sedimentation and a reversal at 5 DAS, especially for the rotary hoe. Potassium showed a high correlation with aluminium $\left(r_{s}=0.89\right)$, iron $\left(r_{s}=0.96\right)$ and silicon $\left(r_{s}=0.87\right)$, and with total solids $\left(r_{s}=0.87\right)$, turbidity $\left(r_{s}=0.79\right)$ and $\operatorname{BOD}\left(r_{s}=0.83\right)$. Potassium can indicate the presence of such minerals as mica in solid particles. The elements $\mathrm{K}, \mathrm{Fe}, \mathrm{Al}$ and $\mathrm{Si}$ are generally present in sediments originating from arable land (Kandler et al., 2017, Kämpf and Curi, 2012). The relationships between some elements or even between attributes in general, are confirmed by the high correlation coefficients between them. In the case of $\mathrm{Si}, \mathrm{Al}$ and $\mathrm{Fe}$, these are always greater than $0.90(\mathrm{p}<0.01)$ and also show the same origin, i.e. particles in suspension, even when they are colloidal in size. The elements $\mathrm{Ca}$ and $\mathrm{Mg}$ also show a high correlation $\left(r_{s}=0.95\right)$.

Ammonia $\mathrm{N}$ also showed a high correlation with the mineral components of iron $\left(r_{s}=\right.$ $0.90)$, silicon $\left(r_{s}=0.78\right)$ and aluminium $\left(r_{s}=0.77\right)$. According to the correlation coefficients for total solids and turbidity $\left(r_{s}=0.81\right)$ for both attributes, these values indicate a loss of mineral nitrogen as soil particles are entrained; there was also a high correlation with $\mathrm{Ca}, \mathrm{S}, \mathrm{Mg}\left(r_{s}=\right.$ 0.80 ), and with $\mathrm{K}$ and $\mathrm{BOD}\left(r_{s}=0.90\right.$ and 0.81 respectively). The levels of micronutrients $\mathrm{Cu}$, $\mathrm{Zn}$ and Mo were mostly below the detection limit (not shown), whereas the levels of Mn were largely detectable; consequently, a comparative statistical analysis between treatments was not carried out as some of the data were missing. Such factors as composition of the organic fertilizer used and the high organic matter content of the soil are probably related to the higher levels of Mn, some of which were above the limit of $0.10 \mathrm{mg} \mathrm{L}^{-1}$ established by CONAMA (2005) for Class II water.

The high correlation between ammonia $\mathrm{N}$ and cations, as well as with the BOD, demonstrate the bonds between organic material and these elements. Permanently saturated soil can preserve organic matter, highlighting the cation adsorption capacity (Silva Netto et al., 2015; Felizolla et al., 2019). Tete et al. (2015) showed that $\mathrm{N}$ may be linked to labile organic compounds formed under waterlogging soil conditions, and this may explain the high correlation between BOD and this element.

As a general tendency, drained waters may show unconformity compared to quality thresholds of government agencies (Table 1). For this reason, its immediate reuse in downstream crops, as well as upstream crops through pumping systems, may be an alternative to be adopted. It consists of a change in the drained water management, with its use for irrigation of crops when the plants are in more advanced development stages. Luminosity reduction may be induced by the water turbidity, promoting an effective control of red rice or other species, preserving rice plants that will be in more advanced stages in their cycle (Lauretti et al., 2001; Noldin et al., 2015; Anghinoni et al., 2020). 
Table 1. Turbidity, Biochemical Oxygen Demand, total solids and total elements of the water used in the treatments.

\begin{tabular}{|c|c|c|c|c|c|c|c|c|c|c|c|c|c|c|c|c|c|c|c|c|c|}
\hline \multicolumn{2}{|c|}{ TREATMENT } & \multicolumn{2}{|c|}{ Total solids } & \multicolumn{2}{|c|}{ BOD (05) } & \multicolumn{2}{|c|}{ Ammonia N } & \multicolumn{2}{|c|}{ Potassium } & \multirow{2}{*}{\multicolumn{2}{|c|}{$\frac{\text { Calcium }}{m g L^{-1}}$}} & \multicolumn{2}{|c|}{ Magnesium } & \multicolumn{2}{|c|}{ Sulphur } & \multicolumn{2}{|c|}{ Iron } & \multicolumn{2}{|c|}{ Aluminium } & \multicolumn{2}{|c|}{ Silicon } \\
\hline \multirow[t]{2}{*}{ Implement } & \multirow{2}{*}{ Drainage $^{1}$} & & & & & & & & & & & & & & & & & & & & \\
\hline & & \multicolumn{20}{|c|}{ Collection at the start of drainage (Hour 0$)$} \\
\hline \multirow{4}{*}{$\mathrm{RH}$} & 0 DAS & 1474.0 & $\mathrm{ab}$ & 101.10 & $\mathrm{a}$ & 2.3 & $a b$ & 3.4 & $\mathrm{a}$ & 37.8 & $\mathrm{a}$ & 15.7 & $\mathrm{a}$ & 1.1 & $\mathrm{~ns}$ & 35.2 & $\mathrm{a}$ & 61.1 & $\mathrm{ab}$ & 91.2 & $\mathrm{a}$ \\
\hline & 2 DAS & 1429.3 & $\mathrm{ab}$ & 83.67 & $a b c$ & 1.5 & $\mathrm{bc}$ & 2.7 & $\mathrm{ab}$ & 35.4 & $\mathrm{ab}$ & 14.3 & $\mathrm{a}$ & 1.0 & & 31.6 & $a b$ & 57.5 & $\mathrm{ab}$ & 95.6 & $\mathrm{a}$ \\
\hline & 3 DAS & 786.7 & $\mathrm{~d}$ & 78.67 & $a b c$ & 0.7 & $\mathrm{~d}$ & 1.9 & $\mathrm{bc}$ & 25.6 & $\mathrm{c}$ & 10.7 & $\mathrm{~b}$ & 0.8 & & 18.7 & bcd & 24.1 & $\mathrm{c}$ & 39.1 & $\mathrm{c}$ \\
\hline & $5 \mathrm{DAS}$ & 1772.7 & $\mathrm{a}$ & 89.33 & $\mathrm{ab}$ & 3.3 & $\mathrm{a}$ & 3.8 & $\mathrm{a}$ & 31.1 & $\mathrm{abc}$ & 10.1 & bc & 1.2 & & 38.7 & $\mathrm{a}$ & 60.9 & $\mathrm{ab}$ & 99.4 & $\mathrm{a}$ \\
\hline \multirow{5}{*}{ LH } & 0 DAS & 1276.0 & $a b c$ & 71.33 & $a b c$ & 0.9 & $\mathrm{~cd}$ & 2.3 & $a b c$ & 26.1 & $\mathrm{bc}$ & 8.4 & $\mathrm{c}$ & 1.0 & & 27.2 & $a b c$ & 62.7 & $\mathrm{a}$ & 97.7 & $\mathrm{a}$ \\
\hline & 2 DAS & 954.7 & bcd & 50.00 & $a b c$ & 0.5 & $\mathrm{~d}$ & 1.4 & $\mathrm{c}$ & 8.7 & $\mathrm{~d}$ & 5.5 & $\mathrm{~d}$ & 0.7 & & 17.2 & $\mathrm{~cd}$ & 41.1 & $a b c$ & 74.3 & $a b$ \\
\hline & 3 DAS & 834.0 & $\mathrm{~cd}$ & 43.33 & $\mathrm{bc}$ & 0.6 & $\mathrm{~d}$ & 1.6 & $\mathrm{bc}$ & 8.5 & $\mathrm{~d}$ & 5.7 & $\mathrm{~d}$ & 0.7 & & 16.8 & $\mathrm{~cd}$ & 35.9 & $a b c$ & 57.3 & $\mathrm{bc}$ \\
\hline & $5 \mathrm{DAS}$ & 848.7 & $\mathrm{~cd}$ & 32.46 & $\mathrm{c}$ & 0.6 & $\mathrm{~d}$ & 1.3 & $\mathrm{c}$ & 8.8 & $\mathrm{~d}$ & 5.5 & $\mathrm{~d}$ & 0.7 & & 13.9 & $\mathrm{~d}$ & 28.1 & $\mathrm{bc}$ & 43.9 & $\mathrm{bc}$ \\
\hline & & \multicolumn{20}{|c|}{ Collection after 6 hours drainage (Hour 6) } \\
\hline \multirow{4}{*}{ RH } & 0 DAS & 2264.0 & $\mathrm{a}$ & 114.70 & $\mathrm{a}$ & 2.3 & $\mathrm{ab}$ & 4.6 & $\mathrm{a}$ & 50.6 & $\mathrm{a}$ & 18.9 & $\mathrm{a}$ & 1.4 & $\mathrm{a}$ & 48.8 & $\mathrm{a}$ & 83.5 & $\mathrm{a}$ & 127.2 & $\mathrm{a}$ \\
\hline & 2 DAS & 1583.3 & $\mathrm{ab}$ & 95.33 & $\mathrm{ab}$ & 1.5 & $\mathrm{bc}$ & 2.9 & $\mathrm{~b}$ & 39.8 & $\mathrm{a}$ & 15.6 & $\mathrm{a}$ & 1.2 & $\mathrm{a}$ & 36.8 & $\mathrm{ab}$ & 66.8 & $a b$ & 103.0 & $\mathrm{a}$ \\
\hline & 3 DAS & 411.3 & $\mathrm{c}$ & 49.67 & $\mathrm{bc}$ & 0.4 & $\mathrm{e}$ & 0.7 & $\mathrm{e}$ & 10.3 & $\mathrm{c}$ & 5.21 & $\mathrm{c}$ & 0.4 & $\mathrm{c}$ & 6.88 & $\mathrm{~d}$ & 14.8 & $\mathrm{c}$ & 19.8 & $\mathrm{c}$ \\
\hline & $5 \mathrm{DAS}$ & 2215.3 & a & 113.70 & $\mathrm{a}$ & 3.7 & $\mathrm{a}$ & 5.2 & a & 33.6 & $\mathrm{a}$ & 11.8 & $\mathrm{ab}$ & 1.3 & $\mathrm{a}$ & 43.7 & $\mathrm{a}$ & 78.3 & $\mathrm{a}$ & 115.3 & $\mathrm{a}$ \\
\hline \multirow{4}{*}{ LH } & 0 DAS & 1310.7 & $\mathrm{ab}$ & 57.33 & $\mathrm{bc}$ & 1.0 & $\mathrm{~cd}$ & 2.1 & $\mathrm{bc}$ & 25.9 & $\mathrm{ab}$ & 8.2 & $\mathrm{bc}$ & 0.9 & $\mathrm{~b}$ & 26.2 & $\mathrm{bc}$ & 55.6 & $\mathrm{ab}$ & 98.2 & $\mathrm{a}$ \\
\hline & 2 DAS & 1600.0 & $\mathrm{ab}$ & 72.00 & $a b c$ & 0.8 & $\mathrm{~d}$ & 3.8 & $\mathrm{~cd}$ & 25.3 & $a b c$ & 8.5 & $\mathrm{bc}$ & 0.9 & $\mathrm{ab}$ & 26.5 & $\mathrm{bc}$ & 66.3 & $a b$ & 89.8 & $a b$ \\
\hline & 3 DAS & 738.7 & $\mathrm{bc}$ & 39.67 & $\mathrm{c}$ & 0.6 & $\mathrm{de}$ & 1.2 & $\mathrm{~d}$ & 10.3 & $\mathrm{bc}$ & 5.9 & $\mathrm{c}$ & 0.4 & $\mathrm{c}$ & 12.8 & $\mathrm{~cd}$ & 24.6 & $\mathrm{bc}$ & 40.9 & $\mathrm{bc}$ \\
\hline & 5 DAS & 1596.7 & $\mathrm{ab}$ & 68.67 & $a b c$ & 0.9 & $\mathrm{~d}$ & 2.2 & $\mathrm{~b}$ & 9.7 & $\mathrm{c}$ & 6.8 & $\mathrm{bc}$ & 0.8 & $\mathrm{~b}$ & 21.8 & bcd & 56.1 & $a b$ & 85.9 & $a b$ \\
\hline \multicolumn{2}{|c|}{ Before planting $-R H$} & \multicolumn{2}{|c|}{1340} & \multicolumn{2}{|c|}{68.5} & \multicolumn{2}{|c|}{1.5} & \multicolumn{2}{|c|}{2.6} & \multicolumn{2}{|c|}{35.1} & \multicolumn{2}{|c|}{14.5} & 0. & & 26 & & 30 & & 70.4 & \\
\hline Before pla & ting $-L H$ & 115 & & 26.5 & & 0.4 & & 0 . & 9 & 6. & 9 & 4 & & 0 . & & 8. & & 17. & & 32.4 & \\
\hline Irrigation & Channel & 240 & & 13.6 & & 0.2 & & 0 . & & 1 . & 4 & 1 & & 0. & & 2. & & 3. & & 8.7 & \\
\hline CONAMA 35 & 7/05 Class II & 500 & & 5 & & 2.00 & & & & & & - & & - & & 0. & & & & - & \\
\hline
\end{tabular}

${ }^{1}$ Days after sowing. ${ }^{2}$ Mean $\mathrm{pH}$ between 7.5 and 8.0. ${ }^{3}$ Intermediate environments. RH: rotary hoe; LH: levelling harrow. Values followed by different letters are statistically different $(\mathrm{p}<0.05)$ by post-hoc Tukey test. $\mathrm{ns}=$ not significant. Phosphorus: submitted to the Kruskal Wallis H-test (nonparametric analysis) and post-hoc Dunn test at $\mathrm{p}<0.05$. Other attributes at $\mathrm{p}<0.05$ by the Shapiro and Wilk normality test (1965), with comparative analysis of variance and Tukey's test at $5 \%$ significance. 
Figure 4 shows the values for the principal component analysis of the selected attributes, represented by the vectors, with the respective treatments under evaluation.

These principal components synthetized $91.2 \%$ of results variability. The relative proximity between treatments shown by the time variable (DAS) can be seen, from which it can be inferred that the implement used in preparing the soil had less influence compared to the time the water remained after sowing. The centroids representing treatments using the hydraulic levelling harrow (LH) are closer, while the treatments with the rotary hoe (RH) appear more dispersed. The results for 5 DAS varied widely, showing a tendency for an increase in the levels of elements and compounds in the drainage water, following a reduction at 3 DAS, mainly in $\mathrm{RH}$. It is estimated that wind gusts reaching higher speeds at $5 \mathrm{DAS}$, associated with greater pulverization of soil, increased susceptibility to particle suspension, which took place five days after sowing (Gonzáles et al., 2013; Marrenjo et al., 2016).

The grouping between attributes can be seen: $\mathrm{Mg}$ and $\mathrm{Ca} ; \mathrm{K}, \mathrm{S}, \mathrm{Fe}, \mathrm{Si}, \mathrm{Al}$ and BOD; ammonia $\mathrm{N}$, total solids and turbidity, demonstrating their close correlation, different from phosphorus which did not present sinificant correlation values with the other attributes.

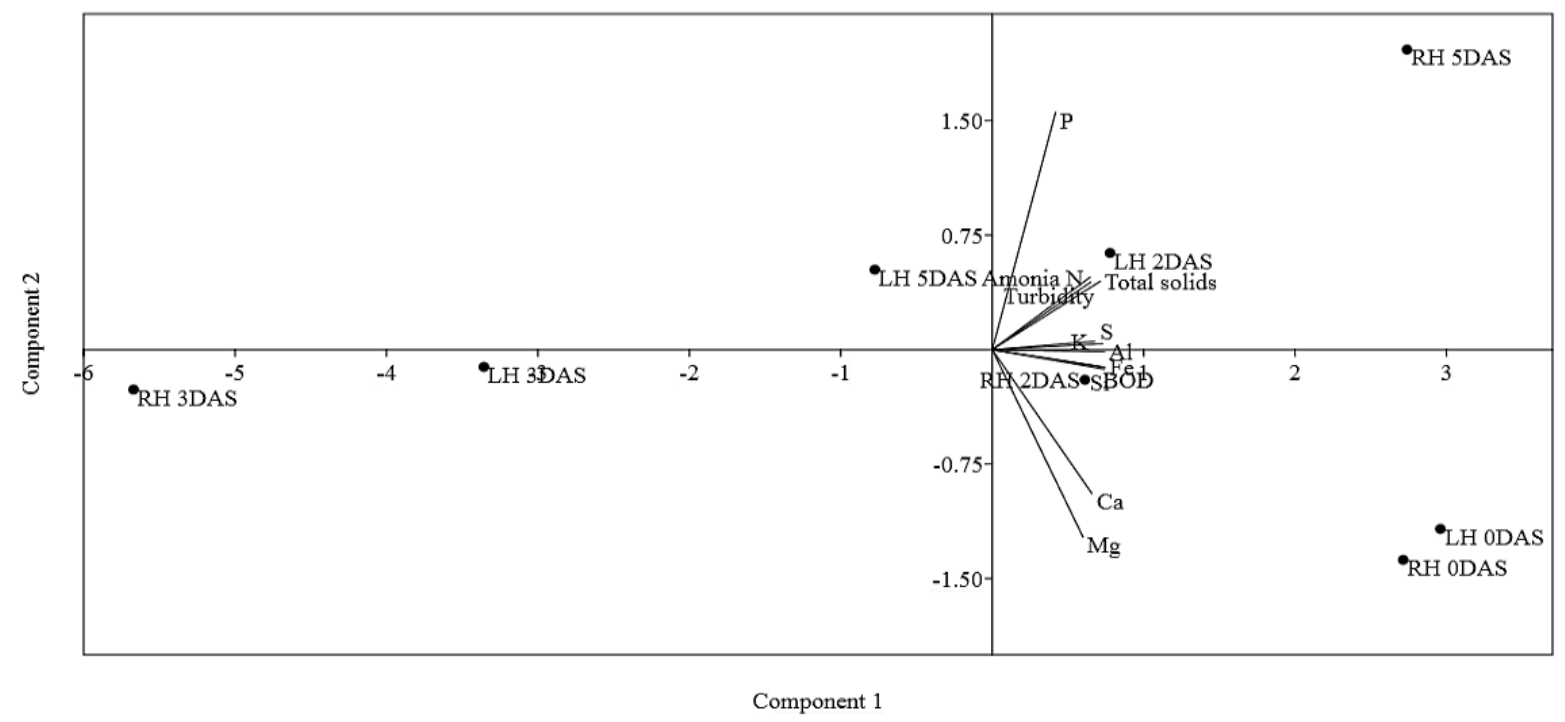

Figure 4. Principal component analysis for 12 attributes evaluated in water drained from crops of pre-germinated irrigated rice under different methods of soil preparation and periods for water remaining in the plots after sowing, for two collection times.

The lowest loss of nutrients - the best results - can be seen in the 3 DAS treatments, when the water remained for a longer period in the areas after sowing. By this logic, the worst results occur in the treatment drained immediately after sowing, mainly for calcium and magnesium.

\section{CONCLUSIONS}

The water drained after sowing rice in a pre-germinated system is unsuitable for release into water courses regardless of the type of management applied, due to the high values for turbidity, total solids, BOD and phosphorus.

Sowing remobilizes some of the elements precipitated during the preceding decanting period, in addition to climate factors, which may favor the suspension of nutrients in the water.

The irrigation water showed values above the limits established by CONAMA 357/05 for $\mathrm{BOD}$ and $\mathrm{P}$, demonstrating the natural characteristics of the water courses in that area.

It can be concluded that there is a need for adapting agricultural practices in the pregerminated system to avoid the loss of soil and nutrients, as well as environmental damage especially to the water resources.

These results showed that management of water in pre-germinated rice cultivation is still 
a challenge, mainly for ecological basis cultivation. Its technological matrix has to be continued, by distinct institutions compromised with this productive system improvement and consolidation.

\section{ACKNOWLEDGMENTS}

The authors wish to thank the Conselho Nacional de Desenvolvimento Científico e Tecnológico $(\mathrm{CNPq})$ for their financial support, linked to the NEXUS II project - Notice MCTIC / CNPq No 20/2017.

\section{REFERENCES}

ABNT. Nbr 12620:1992: Águas - Determinação de nitrato - Métodos do ácido cromotrópico e do ácido fenoldissulfônico - Método de ensaio. Rio de Janeiro, 1992. 5 p.

ANGHINONI, I.; PORTELA, E.; DIEL, R.; ZANG, M. (Eds.). Fundamentos, manejo e perspectivas da produção de arroz irrigado de base ecológica no Rio Grande do Sul. Cachoeirinha: IRGA/Estação Experimental do Arroz, 2020. 77p. Boletim Técnico.

AVILA, L. A. de; MARCHEZAN, E.; MACHADO, S. L. de O. et al. Sistemas de cultivo de arroz (Oryza sativa L.) irrigado: controle de arroz vermelho (Oryza sativa L.) e de capim arroz (Echinochloa spp.). In: REUNIÃO DA CULTURA DO ARROZ IRRIGADO, 22., 1997, Balneário Camboriú. Anais[...] Itajaí: EPAGRI, 1997. p. 459-461.

APHA; AWWA; WEF. Standard Methods for the examination of water and wastewater. 23nd ed. Washington, 2017. 1504 p.

CARLOS, F. S. et al. Evolução da produtividade de arroz irrigado sob diferentes sistemas de manejo do solo por longo prazo. In: CONGRESSO BRASILEIRO DE ARROZ IRRIGADO, 9., 2015, Pelotas-RS. Ciência e Tecnologia para Otimização da Orizicultura. 2015. 4 p. Available at: http://www.cbai2015.com.br/docs/trab-5-7899245.pdf. Access: 15 Dec. 2018.

CGHG. Plano de recursos hídricos da bacia hidrográfica do rio Gravataí. Porto Alegre, 2012. 582 p.

CONAMA (Brasil). Resolução n 357 de 17 de março de 2005. Dispõe sobre a classificação dos corpos de água e diretrizes ambientais para o seu enquadramento, bem como estabelece as condições e padrões de lançamento de efluentes, e dá outras providências. Diário Oficial [da] União: seção 1, Brasília, DF, n. 053, p. 58-63, 18 mar. 2005.

CPRM. Mapa Geológico do Estado do Rio Grande do Sul. Escala 1:750.000. Projeto Geologia do Brasil ao Milionésimo. 2008.

EMBRAPA. Sistema Brasileiro de Classificação do Solo. 5. ed. Brasília, DF, 2018. 356 p.

FELIZOLLA, J. F.; CAK, A. D.; FIGUEIREDO, R. O.; LIMA, M. O. Metals and dissolved organic carbon (DOC) of surface waters in two adjacent watersheds in the eastern Amazon. Revista Ambiente \& Água, v. 14, n. 6, 2019. https://dx.doi.org/10.4136/ambiagua. 2377

FEPAM. Relatório da qualidade da água superficial do estado do Rio Grande do Sul. 2020. 87 p. Available at: http://www.fepam.rs.gov.br/biblioteca/relat_aguas_superf.asp. Access: 09 June 2020.

FERREIRA, D. F. Estatística Multivariada. Lavras: Ed. Universidade Federal de Lavras, 2008. $622 \mathrm{p}$. 
GARCIA, G. A. et al. Manejo da adubação fosfatada e potássica no sistema pré-germinado de cultivo de arroz irrigado. In: CONGRESSO BRASILEIRO DE ARROZ IRRIGADO, 4.; REUNIÃO DA CULTURA DO ARROZ IRRIGADO, 26., 2005, Santa Maria. Anais[...] Porto Alegre: IRGA, 2005.

GUERRA, L. C.; BHUYIAN, S. I.; TUONG, T. P.; BARKER, R. Producing more rice with less water from irrigated systems. Colombo: SWIM, 1998. p. 1-34. (Technical Paper, $5)$.

GONZÁLES, H.; CAPPELLI; N. L.; TORO, A. Wear of rotary plows operating in a tropical clay loam soil. Engenharia Agrícola, v. 33, n. 4, p.772-781, 2013. https://doi.org/10.1590/S0100-69162013000400017

IRGA. Boletim de resultados da lavoura - safra 2018/19. Porto Alegre, 2019. 16 p.

IUSS WORKING GROUP WRB: World Reference Base for Soil Resources 2014, Update 2015. World 444 Soil Resources Reports 106. Rome: FAO, 2015.

KÄMPF, N.; CURI N. Formação e evolução do solo (Pedogênese). In: KER, J. C.; CURI, N.; SCHAEFER, C. E. G. R.; VIDALTORRADO, P. (eds.). Pedologia: fundamentos. Viçosa: SBCS, 2012. p. 207-302.

KANDLER, M. et al. Impact of land use on water quality in the upper Nisa catchment in the Czech Republic and in Germany. Science of the total Environment, v. 586, p. 516- 525, 2017. https://doi.org/10.1016/j.scitotenv.2016.10.221

KUPKANCHANAKUL, W.; KADOWAKI, M.; KUBOTA, M.; NAIVIKUL, O. Effect of pre-germination at varying stages of embryonic growth length on chemical composition and protein profile of Thai rice (Oryza sativa L.). Agriculture and natural Resources, v. 52, p. 59-65, 2018. https://doi.org/10.1016/j.anres.2018.05.009

LAURETTI, R. L. B. et al. Efeitos de diferentes manejos de água no estabelecimento de plantas de arroz no sistema pré-germinado. Pesquisa agropecuária brasileira, v. 36, n. 9, p. 1093-1099, 2001. https://doi.org/10.1590/S0100-204X2001000900002

MACEDO, V. R. M. et al. Perdas de solo e nutrientes na água de drenagem durante o preparo do solo para o sistema de cultivo de arroz pré-germinado. In: CONGRESSO BRASILEIRO DE ARROZ IRRIGADO, 2.; REUNIÃO DA CULTURA DO ARROZ IRRIGADO, 24., 2001, Porto Alegre, RS. Anais[...] Porto Alegre: IRGA, 2001. p. $247-$ 249.

MACHADO, S. L. DE O. et al. Consumo de água e perdas de nutrientes e de sedimentos na água de drenagem inicial do arroz irrigado. Ciência Rural, v. 36, n. 1, p. 65-71, 2006. https://doi.org/10.1590/S0103-84782006000100010

MARCHEZAN, E.; CAMARGO, E. R.; SEGABINAZZI, T. Manejo dos fertilizantes fosfatados e potássicos em arroz irrigado no sistema pré-germinado. Bragantia, v. 66, n. 2, p. 219-226, 2007a. https://doi.org/10.1590/S0006-87052007000200005

MARCHEZAN, E. et al. Manejo da adubação do arroz irrigado em sistema pré-germinado na produtividade e perda de nutrientes através da água de drenagem inicial. Ciência Rural, v. 31, n. 5, p. 877-879, 2001. https://doi.org/10.1590/S0103-84782001000500023

MARCHEZAN, E. et al. Manejo da irrigação em cultivares de arroz no sistema pré-germinado. Ciência Rural, v. 37, n. 1, p. 45-50, 2007b. http://dx.doi.org/10.1590/S010384782007000100008 
MARRENJO, G. J. et al. Impactos do cultivo por longo tempo de arroz inundado em Gleissolos. Pesquisa Agropecuária Brasileira, v. 51, n. 8, p. 967-977, 2016. http://dx.doi.org/10.1590/S0100-204X2016000800009

MATTOS, M. L. T. et al. Qualidade da água de drenagem em cultivo de arroz prégerminado. Pelotas: EMBRAPA, 2012. 6 p. Circular Técnica.

MILJOJKOVIC, D.; TREPSIC, I.; MILOVANCEVIC, M. Assessment of physical and chemical indicators on water turbidity. Physica A, Amsterdam, v. 527, p. 1 - 5, 2019. https://doi.org/10.1016/j.physa.2019.121171

MIRANDA, F. Q.; ZARNOTT, A. Z.; NEUMANN, P. S.; FIALHO, A. V. Sistema de produção de arroz dos assentamentos do Rio Grande do Sul. Santa Maria: UFSM, 2016. 28 p.

MOLOZZI, J.; PINHEIRO, A.; SILVA, R. M. Qualidade da água em diferentes estádios de desenvolvimento do arroz irrigado. Pesquisa agropecuária brasileira, v. 41, n. 9, 2006. https://doi.org/10.1590/S0100-204X2006000900007

NASCIMENTO, P. C.; LANI, J. L.; ZOFFOLI, H. J. O.; PEIXTO, H. T. M. Teores e características da matéria orgânica de solos hidromórficos do Espírito Santo. Revista Brasileira de Ciência do Solo, v. 34, p. 339-348, 2010. http://dx.doi.org/10.1590/S010006832010000200007

NOLDIN. J. A. et al. Recomendações técnicas para a produção de arroz irrigado em sistema orgânico em Santa Catarina. Florianópolis: Epagri, 2015. 40 p. (Epagri. Sistemas de Produção, 47).

PETRINI, J. A. et al. Sistema de cultivo de arroz pré-germinado e transplante de mudas. In: GOMES, A. S.; MAGALHÃES JÚNIOR, A. M. (ed.). Arroz irrigado no Sul do Brasil. Brasília - DF: EMBRAPA, 2004. p 387- 416.

SCIVITTARO, W. B. et al. Monitoramento da qualidade da água de drenagem inicial de lavoura de arroz pré- germinado. Pelotas: Embrapa Clima Temperado, 2010. 8 p. (Embrapa Clima Temperado. Circular técnica, 97).

SHALLAN, M. A.; EL-BELTAGI, H. S.; MONA, A. M.; AMERA, T. M. Chemical evaluation of pre-germinated brown rice and whole grain rice bread. Electrical Journal of Environment, Agriculture and Food Science, v. 3, p. 958-971, 2010.

SHAPIRO, S. S.; WILK, M. B. Analysis of variance test for normality (complete samples). Biometrika, v. 52, p. 591-611, 1965. https://doi.org/10.2307/2333709

SILVA NETO, L. F. et al. Characterization and classification of floodplain soils in the Porto Alegre metropolitan region, RS, Brazil. Ciência e Agrotecnologia, v. 39, n. 5, p. 423434, 2015. http://dx.doi.org/10.1590/S1413-70542015000500001

SOSBAI. Arroz irrigado: recomendações técnicas da pesquisa para o Sul do Brasil. In: REUNIÃO TÉCNICA DA CULTURA DO ARROZ IRRIGADO, 32., 2018, Farroupilha, RS. Anais[...] Cachoeirinha, RS: Palotti, 2018. 205 p.

TADESSE, F. T.; DECHASSA, R. N.; BADU, W.; GEBEYEHU, S. Effect of hydro-priming and pre-germinating rice seed on the yield and terminal moisture stress mitigation of rainfed lowland rice. Agriculture, Forestry and Fisheries, v. 2, p. 89-97, 2013.

TELLES, D. D.; GÓIS, J. S. de. (coord.). Ciclo ambiental da água: da chuva à gestão. 1. ed. São Paulo: Blutcher, 2013. 496 p. 
TETE, E.; VIAUD, V.; WALTER, C. Organic carbon and nitrogen mineralization in a poorlydrained mineral soil under transient waterlogged conditions: an incubation experiment. European Journal of Soil Science, v. 66, n. 3, p. 427-437, 2015. https://dx.doi.org/10.1111/ejss.12234

TONTHONG, Y.; CHANPRASERT, W.; ROMKAEV, J.; KAEWSORN, P. Germinability and storability of pre-germinated rice (Oriza sativa L.) seeds. Seed Science and Technology, v. 46, p. 119-129, 2018. https://doi.org/10.15258/sst.2018.46.1.12

UPADHYAY, G.; RAHEMAN, H. Comparative analysis of tillage in sandy clay loam soil by free rolling and powered disc harrow. Engineering in Agriculture, Environment and Food, v. 12, n. 1, p. 118-125, 2019. https://dx.doi.org/doi.org/10.1016/j.eaef.2018.11.001

VIGNOLO, A. M. S. Insumos orgânicos na produção de arroz em assentamentos da reforma agrária, região de Porto Alegre/RS. 2010. 70p. Dissertação (Mestrado) Universidade Federal de Santa Catarina, Florianópolis, 2010.

WEBER, L. et al. Cultivares de arroz irrigado e nutrientes na água de drenagem em diferentes sistemas de cultivos. Ciência Rural, v. 33, n. 1, p. 27-33, 2003. https://doi.org/10.1590/S0103-84782003000100005

WEIDHUNER, A. et al. Tillage impact on soil aggregation and aggregate-associated Carbon and Nitrogen after 49 years. Soil \& Tillage Research, v. 208, 2021. https://doi.org/10.1016/j.still.2020.104878

ZANG, M. Qualidade de solos hidromórficos sob arroz ecológico. 2020. 113 p. Dissertação (Mestrado) - Programa de Pós-Graduação em Ciência do Solo, Faculdade de Agronomia, Universidade Federal do Rio Grande do Sul, Porto Alegre, 2020. 